\author{
Ewa Wanda Maruszewska \\ University of Economics in Katowice \\ e-mail: ewa.maruszewska@ue.katowice.pl \\ ORCID: 0000-0003-0461-4133
}

\title{
THE PERCEPTION OF DISCRETIONARY ACCOUNTING REGULATIONS ON ASSET WRITE-OFFS
}

\section{POSTRZEGANIE ELASTYCZNYCH REGULACJI RACHUNKOWOŚCI W ZAKRESIE ODPISÓW AKTUALIZUJĄCYCH AKTYWA}

DOI: $10.15611 / \mathrm{pn} .2019 .12 .06$

JEL Classification: G41, M41

\begin{abstract}
Summary: Flexibility of accounting norms (in the scope of asset write-offs) was introduced in order to enable entities to apply solutions adjusted to their specific character, creating+-* the possibility to use discrete decision-making in a way that undermines the theoretical foundations of accounting. The disfunction lowers the faithful representation of financial reports. The aim of this study is to analyse the perception of discrete accounting in the context of financial reporting. The study was conducted among part-time accounting students with the high level of previous accounting experience. The findings showed that the respondents were not eager to use write-offs for manipulation purposes but were strongly convinced that other accountants would behave unethically. They also suggested that faithful representation is not perceived as a social norm among accounting professionals and that the perception of asset write-offs differs depending on the group of assets. In the conclusion, the study indicated a gap between the theoretical foundations of accounting and their application in business practice.
\end{abstract}

Keywords: write-offs, impairment of assets, decision making in accounting, financial reporting.

Streszczenie: Elastyczność regulacji rachunkowości w obszarze odpisów aktualizujących, choć wprowadzona dla umożliwienia dostosowania szczegółowych rozwiązań do sytuacji przedsiębiorstwa, stanowi sposobność do dokonania wyboru niweczącego założenia teorii rachunkowości o etycznej aplikacji prawa o rachunkowości. Zaburzenie w tym zakresie zmniejsza wiarygodność informacji finansowych. Celem publikacji jest zbadanie postrzegania elastycznych regulacji rachunkowości w zakresie sprawozdawczości finansowej. Badanie przeprowadzono w formie anonimowej ankiety wśród studentów, którzy w dużej mierze mieli już doświadczenie w rachunkowości. Uzyskane wyniki pokazały, że choć ankietowani nie byli skłonni do nieetycznego wykorzystania odpisów aktualizujących, to wskazali, iż w ich opinii inni księgowi tak właśnie by postąpili. Badanie sugeruje również brak postrzegania 
konieczności dbania o wiarygodność jako normy obowiązującej w tej grupie zawodowej oraz wskazuje na zróżnicowane postrzeganie możliwości odstąpienia od odpisów aktualizujących w zależności od składnika aktywów, którego trwała utrata wartości dotyczy. Badanie wykazało także istniejący rozdźwięk pomiędzy założeniami teorii rachunkowości a aplikowaniem jej w praktyce gospodarczej.

Słowa kluczowe: odpisy aktualizujące, utrata wartości, podejmowanie decyzji w rachunkowości, sprawozdawczość finansowa.

\section{Introduction}

Flexible accounting regulations allow for tailoring detailed solutions (within the accounting policy) according to the diverse and changing situation of an entity. However, proper application of discrete accounting, in the absence of technical guidance and boundary conditions for the utilization of specific solutions and simplifications, requires due diligence from the accounting services, which minimizes the risk of distorting the financial overview of the entity and/or omitting material information. An important role in the correct application of flexible accounting standards is also played by an ethical attitude which - within the discretion provided by the legislature - is the only guarantor that the assumptions of accounting theory in a given situation will be complied with. The professional, including ethical, application of discrete accounting regulations is aimed at preparing high quality financial reports, i.e. characterised by qualitative features indicated in the conceptual assumptions of usefulness and reliability [International Financial Reporting Standards Foundation 2018].

Meanwhile, the mass media have been giving extensive coverage of scandals involving accounting services and often indicated that the priority was given to rational action (i.e. economically justified) over ethical standards [Maruszewska 2014, p. 128]. In connection with the above, it is interesting to examine the propensity towards behaviour that undermines the reliability of financial statements. Therefore, asset write-offs were selected for the study as they play an important role in shaping an entity's situation, as it is left to the discretion of the entity to increase the reliability of information or to achieve ad hoc goals. In addition, the hypothesis was assumed that the perception of refraining from asset write-offs is inconsistent, depending on the asset concerned. To verify the hypothesis, the study applied a semantic scale described by antonyms from the area of legal and economic terms as well as terms describing the personal attitudes of decision-makers.

\section{Asset write-offs in Polish accounting law}

The category of asset write-offs is related to permanent impairment as defined in art. 28 par. 7 of the Accounting Act (the Act). The asset write-off is an accounting 
reflection of the probability that the controlled asset will not bring in the whole (or in part) the anticipated economic benefits. The Act's provisions, in addition to the general indication of the situation obliging to write-offs, also include regulations referring to precisely indicated groups of assets, clearly describing situations that constitute the basis for the determination of the permanent impairment of tangible assets and receivables (art. 32 par. 4 and art. 35b par. 1 of the Act). Despite the fact that the indicated examples are the cause of impairment, unconditional determination of the occurrence of a given premise is not always easily practicable. Ambiguous situations or the possibility of different perceptions of a given case may encourage the presentation of an event in a way that would help achieve a favourable, but not neutrally described, situation. In this case the accounting practice does not provide conditions taken for granted by the regulators. The human factor actively undermines the true and fair view of the entity in the financial statement through the use of accounting flexibility, to present a distorted impression of the financial position of the entity.

Since the determination of the financial picture takes place at the level of the description of economic reality, in the absence of the possibility (or significantly hindered possibility) of verifying the factual situation, it seems almost impossible to detect an incorrect conduct. This is due to the fact that based on a distorted description of reality, which does not indicate the need for asset write-offs, it is difficult - just based on the analysis of legal compliance - to challenge the adopted procedure. Therefore, not only is the perception of permanent impairment in terms of compliance with the accounting law, but also in the field of professional ethics, essential to ensure that, in business practice, the application of the available solutions takes place in conditions compliant to the theoretical assumptions adopted by the legislator and therefore results in reliable financial information.

\section{Past behavioural accounting research}

Research in the field of behavioural accounting mostly focuses on incentives that affect decision-makers, mainly managers. A number of studies are based on the manipulation of factors that encourage managers to act for their own immediate benefit. A large part of research focuses on decision-making in the area of management accounting, including budget planning or project evaluation [Booth, Schultz 2004; Stronczek 2011; Boedker, Chua 2013; Mazurowska 2014; Simnett, Trotman 2018]. In turn, research in the field of financial accounting is mainly focused on the influence of, among others, the organizational, ethical or personality determinants on earnings management [Towry 2003; Nowak 2016; Abernethy et al. 2017]. There is also a stream of literature referring to auditors [Birnberg 2011; Brown, Popova 2016], but as they are not experiencing the employee-employer relation, the findings presented in these studies are of limited use for accountants' decision-making. Research aimed at making choices in the context of accounting 
policy as an incentive most often assumes the impact on stakeholders, in particular owners [Anderson et al., 2015]. A manager is indicated as a decision-maker, whodue to the function performed - is interested in obtaining approval for the presented view of the entity's financial situation.

However, accountants do not always have to be aware of the objectives pursued by the top management. Without a direct stimulus, which is an incentive for unethical behaviour, accountants should unconditionally focus their actions on providing reliable financial information. Ethical behaviour may also result from social norms. Thus in addition, the existence of a social norm is investigated in order to verify whether in the presence of discretionary accounting, a binding social norm can 'guard' the reliability of financial information. The social norm activation model was based on the study by Bicchieri [2015, quoted in Blay et al. 2018]. The aim of incorporating social norm model was to examine whether discretionary accounting in the scope of asset write-offs is perceived as a binding social norm. In cases when ethics are not incorporated in the decision-making process, social norms may act as a safeguard ensuring the proper application of accounting regulations.

The above leads the author to the hypothesis of this study that the perception of refraining from asset write-offs is inconsistent, depending on the asset concerned. The author assumes that propensity to manipulate assets write-offs differs depending on the asset type and it ultimately affects the reliability of financial reports. Finally, the author investigates if the need to produce reliable financial data can be seen as a social norm.

\section{Description of the study and characteristics of the respondents}

The study was conducted among university part-time students who completed the course 'Financial Reporting,' which was mainly prompted by the need to provide up-to-date knowledge on the creation of impairment allowances. The study was conducted in the form of an anonymous questionnaire, in which the respondent made a choice in the described hypothetical situation of an enterprise operating in Poland. The basic scale used in the survey questionnaire was a 5-point Likert scale and a semantic differential was adopted to study attitudes towards the described situations regarding discretionary accounting.

The presented situations concerned asset write-offs and referred to the forecasted problems with the collection of receivables and defectiveness of a tangible asset. Both situations were described in an identical manner, i.e. the structure of the survey questionnaire contained the following elements:

- information on the role of the subject acting as the chief accountant and on the obligation to decide whether to book asset write-offs or to refrain from them during preparation of financial reports,

- a description indicating the occurrence of impairment loss and the need to take an asset write-off, i.e. demonstrating the threat of recoverability of receivables 
and a mechanical defect resulting in a shorter period of its use than originally assumed,

- an indication of the consequences of booking an asset write-off in the form of a decline in the financial result,

- information that the chief accountant decides autonomously, and that independent auditors have little chance to challenge the decision made by the chief accountant.

In the following part of the survey, the respondents were asked to determine their propensity to refrain from asset write-offs, express their opinion on social standards and validate refraining from asset write-offs on a multidimensional scale.

The study covered 114 part-time graduate students of an accounting faculty at a public university in Poland. The respondents were generally of $21-25$ years of age $(n=88 ; 81 \%)$. The remaining respondents were older but did not exceed 40 years of age. $83 \%$ of respondents $(n=95)$ indicated that they already had practical experience, with $60 \%(n=65)$ strictly in accounting. Most of the respondents indicated practical experience below five years $(n=64 ; 60 \%)$. Only two respondents held top managerial positions or were the owners of the enterprise. Most of them worked in middle $(n=30 ; 26 \%)$ and lower-level $(n=61 ; 54 \%)$ positions; $39 \%$ of respondents $(n=$ 44 ) indicated that they worked in micro enterprises, and $17 \%$ in small enterprises $(n=19)$. In turn, 9\% declared employment in a medium-sized entity $(n=10)$ and $21 \%$ in a large one $(n=24)$. Interestingly, many of the respondents indicated that they already had a background (secondary or higher) in economics $(n=48 ; 42 \%)$.

The presented characteristics of the respondents determine the analysis of the results obtained. The interpretation of results cannot be generalized to all people dealing with accounting, in particular to practitioners with many years of experience, but it can be the basis for analysing the perception of discretionary accounting regulations, including the perception of reliability as a social norm of this professional group, in particular future accounting services.

\section{Results}

Descriptive statistics (Table 1) indicate the propensity to take asset write-offs regardless of the consequences in the form of lowering the financial results $(n=35$, $62.5 \%$ in the receivables case and $n=33,56.9 \%$ in the situation regarding tangible assets). There were no statistically significant differences between the respondents' choices who made the decision on the receivables and those who decided about the write-off of tangible assets $(t(111.56)=0.387, p=.699)$.

In the second part of the survey (Table 2), $62.3 \%$ of respondents $(n=71)$ indicated that accounting regulations in the field of write-offs are sufficient, concluding at the same time that it is difficult to reach a decision $(n=77,67.5 \%)$. An interesting result was obtained from the comparison of opinions on two statements contained in the questionnaire: a view of how other accountants would act in such a situation, 
Table 1. Descriptive statistics on the propensity of respondents to refrain from write-offs

\begin{tabular}{|l|c|c|}
\hline & $\begin{array}{c}\text { Propensity to refrain } \\
\text { from write-off on receivables }\end{array}$ & $\begin{array}{c}\text { Propensity to refrain } \\
\text { from write-off on tangible assets }\end{array}$ \\
\hline Number of answers & 56 & 58 \\
\hline Median & 4.0 & 4.0 \\
\hline Minimum & 1 & 1 \\
\hline Maximum & 5 & 5 \\
\hline Standard deviation & 1.111 & 1.225 \\
\hline Mode & 4.0 & 4.0 \\
\hline Average & 3.464 & 3.379 \\
\hline
\end{tabular}

* Scale 1-5, where 1 means 'I am definitely willing to refrain from write-offs' and 5 indicates 'I am definitely not willing to refrain from write-offs'.

Source: own elaboration.

Table 2. The number of answers to questions on compliance with standards

\begin{tabular}{|c|c|c|c|c|}
\hline $\begin{array}{c}\text { The } \\
\text { number }\end{array}$ & $\begin{array}{l}\text { Accounting } \\
\text { regulations on } \\
\text { write-offs are } \\
\text { sufficient (1) / } \\
\text { insufficient (5) }\end{array}$ & $\begin{array}{l}\text { I find the decision } \\
\text { in the case } \\
\text { described } \\
\text { as easy (1) / } \\
\text { difficult (5) }\end{array}$ & $\begin{array}{l}\text { Other accountants } \\
\text { in the described } \\
\text { case would make } \\
\text { a decision based } \\
\text { on legal } \\
\text { regulations (1) / } \\
\text { existing practice (5) }\end{array}$ & $\begin{array}{l}\text { The statutory auditor } \\
\text { would base } \\
\text { the accuracy review } \\
\text { of the described case on } \\
\text { legal regulations (1)/ } \\
\text { the existing practices } \\
\text { in the firm (5) }\end{array}$ \\
\hline \multicolumn{5}{|c|}{$n=114$} \\
\hline (1) & $19(16.7 \%)$ & $5(4.4 \%)$ & $10(8.8 \%)$ & $63(55.3 \%)$ \\
\hline (2) & $52(45.6 \%)$ & $18(15.8 \%)$ & $19(16.7 \%)$ & $31(27.2 \%)$ \\
\hline (3) & $22(19.3 \%)$ & $14(12.3 \%)$ & $7(6.1 \%)$ & $9(7.9 \%)$ \\
\hline (4) & $21(18.4 \%)$ & $52(45.6 \%)$ & $40(35.1 \%)$ & $8(7.0 \%)$ \\
\hline (5) & $0(0 \%)$ & $25(21.9 \%)$ & $38(33.3 \%)$ & $3(2.6 \%)$ \\
\hline Median & 2 & 4 & 4 & 1 \\
\hline Minimum & 1 & 1 & 1 & 1 \\
\hline Maximum & 4 & 5 & 5 & 5 \\
\hline $\begin{array}{l}\text { Standard } \\
\text { deviation }\end{array}$ & 0.974 & 1.120 & 1.327 & 1.045 \\
\hline Mode & 2 & 4 & 4 & 1 \\
\hline
\end{tabular}

Source: own elaboration.

and what would be the most important, how to review the accuracy of the adopted solution for the statutory auditor. In this case $68.4 \%(n=78)$ of respondents believe that other accountants would make choices based on the firm's existing practice, and only $25.5 \%(n=29)$ indicated accounting regulations as the basis for decisions 
made by other accountants. The reverse distribution of answers was obtained for the statement regarding the accuracy of the valuation of receivables made by the statutory auditor; $82.5 \%(n=94)$ of the respondents considered legal regulations as the basis for the assessment, and only $9.6 \%(n=11)$ declared the existing practice of the entity.

The analysis of the results of semantic differential was preceded by the reliability verification, which was carried out based on Cronbach's alpha ratio separately for the case of write-offs for receivables and tangible assets. In both cases, the reliability of the collected responses was confirmed, resulting in high rates, i.e. for the receivables $\alpha=.761$ and for the tangible assets $\alpha=.772$.

Table 3. Descriptive statistics on the study semantic scale

\begin{tabular}{|c|c|c|c|c|c|c|c|c|c|c|c|}
\hline \multirow{2}{*}{$\begin{array}{l}\text { Defined perception } \\
\text { of refraining from write-offs }\end{array}$} & \multicolumn{5}{|c|}{$\begin{array}{l}\text { Receivables' write-offs } \\
\qquad n=56\end{array}$} & \multicolumn{5}{|c|}{$\begin{array}{l}\text { Fixed assets' write-offs } \\
\qquad n=58\end{array}$} & \multirow{2}{*}{$\begin{array}{c}\text { Mann- } \\
\text { - Whitney } \\
\text { Test U } \\
\\
\alpha=.05\end{array}$} \\
\hline & 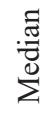 & $\stackrel{\Xi}{\Sigma}$ & $\sum_{\Sigma}^{\star \star x}$ & 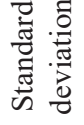 & $\frac{\pi}{8}$ & 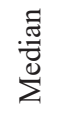 & $\Xi$ & $\stackrel{x}{a}$ & 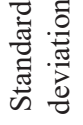 & $\frac{\pi}{8}$ & \\
\hline $\begin{array}{l}\text { Consistent with the } \\
\text { foundations of accounting / } \\
\text { Inconsistent with ... }\end{array}$ & 6.0 & 1 & 7 & 1.88 & 7 & 6.0 & 1 & 7 & 1.66 & 7 & .838 \\
\hline $\begin{array}{l}\text { In conformity with the law/in } \\
\text { non-conformity with the law }\end{array}$ & 6.0 & 1 & 7 & 2.11 & 7 & 6.0 & 1 & 7 & 1.87 & 7 & .465 \\
\hline Mandatory / Voluntary & 5.0 & 1 & 7 & 1.99 & 6 & 6.0 & 1 & 7 & 1.89 & 7 & .275 \\
\hline $\begin{array}{l}\text { Acceptable by existing } \\
\text { practice / Unacceptable ... }\end{array}$ & 5.0 & 2 & 7 & 1.52 & 5 & 4.0 & 1 & 7 & 2.01 & 2 & .028 \\
\hline $\begin{array}{l}\text { Justified by the firm's } \\
\text { situation / Unjustified ... }\end{array}$ & 5.0 & 1 & 7 & 1.81 & 5 & 4.5 & 1 & 7 & 1.96 & 7 & .543 \\
\hline $\begin{array}{l}\text { Economically justified / } \\
\text { Economically unjustified }\end{array}$ & 5.0 & 1 & 7 & 1.95 & 6 & 5.0 & 1 & 7 & 2.17 & 6 & .878 \\
\hline Fair / Unfair & 5.0 & 2 & 7 & 1.89 & 6 & 5.0 & 2 & 7 & 1.33 & 6 & .544 \\
\hline $\begin{array}{l}\text { Culturally acceptable / } \\
\text { Culturally unacceptable }\end{array}$ & 4.0 & 1 & 6 & 1.75 & 6 & 3.0 & 1 & 7 & 1.89 & 2 & .077 \\
\hline Egoistic/ Altruistic & 4.0 & 1 & 7 & 1.61 & 3 & 5.0 & 1 & 7 & 1.91 & 7 & .002 \\
\hline $\begin{array}{l}\text { Bringing personal benefits } \\
\text { to the accountant / Causing } \\
\text { personal damage to the } \\
\text { accountant }\end{array}$ & 2.0 & 1 & 6 & 1.62 & 1 & 4.0 & 1 & 7 & 1.58 & 4 & .002 \\
\hline Ethical/Unethical & 4.5 & 1 & 7 & 1.92 & 7 & 5.0 & 1 & 7 & 2.04 & 7 & .574 \\
\hline
\end{tabular}

Source: own elaboration. 
Linked statements were set out on the semantic scale and they concerned three areas: legal, economic and referring to the person making the decision on refraining (or not) from asset write-offs (Table 3). The obtained results indicate the unequivocal belief of the respondents that refraining from write-offs is inconsistent with the theoretical foundations of accounting as well as accounting law. Most of the respondents are convinced of the voluntary nature of the described decision-making situation and believe that neither the economic situation nor the existing practice of the enterprise may allow for such behaviour. Furthermore, the respondents who participated in the study expressed the strong conviction that 'refraining' is an unfair behaviour, and no respondent chose 'decisively fair' by marking the value ' 1 ' on the multidimensional scale. This finding is interesting when contrasted with the belief that 'refraining from asset write-offs is unethical' is rather weak among both groups of respondents.

A stronger belief in accepting refraining from the existing practice was expressed by those participating in the experiment on tangible assets $((M d n=5 ; M=5)$, $U=1241.5 ; p=.028)$. On the one hand, the discrepancy between knowledge in the field of accounting theory and legal regulations, and, on the other, the perception of accounting practice also revealed answers to questions from the group of economic reasons. While the respondents did not have a clear opinion on whether refraining from asset write-offs can be justified by the situation of the firm or by the economic justification, culturally acceptable refraining from write-offs of tangibles was strongly indicated among respondents working with tangibles in the survey $\left((M d n=4 ; M=6), U=1267.0 ; p=.077 ; \chi^{2}(6, N=114)=12.674, p=.047\right)$.

Interestingly, the respondents participating in the experiment on receivables, considered refraining from asset write-offs as more egoistic $(n=27 ; 48 \%)$ and at the same time expressed the firm opinion that the decision-maker would gain personal benefits $(\mathrm{n}=39 ; 61 \%)$. In contrast, subjects participating in the survey with tangible assets expressed the stronger opinion that such behaviour is not egoistic $(n=34$; $58,6 \% ;(M d n=4 ; M=4), U=2153.0 ; p=.002)$ and may cause personal damage to the accountant $(n=35 ; 25,9 \% ;(M d n=3 ; M=4), U=2151.0 ; p=.002)$.

\section{Discussion}

The obtained results confirm that - in the absence of a direct stimulus to unethical behaviour - most respondents would show a propensity to act in favour of a true and fair view of the entity. At the same time, the results suggest that one-third of the respondents perceive refraining from asset write-offs as possible. This may result in unreliable financial information if taken together with the result indicating that a similar number of subjects consider refraining from asset write-offs as ethical.

In this context, an interesting result is the belief that other accountants would behave differently in this situation than the respondents and would be guided by the existing practice of the firm rather than the assumptions of accounting theory. 
The demonstrated dissonance did not repeat itself in the perception of the statutory auditor. In the opinion of the respondents, the expert professional would base his/ her conclusions on legal regulations (as most of the respondents made the decision) and not on the existing practice of the entity. Referring to the model of social norm activation, the above observation may indicate that reliability is not clearly perceived as a binding social norm. Social norms exist and are used in a specific community if two conditions are met. Firstly, every member of the community is aware that they are in a situation where this norm is in force. Secondly, each member of the community prefers to apply the norm on the basis of two conditions: (1) the belief that most people also follow this norm; and (2) the belief that others expect the norm to be inappropriate. In a situation where the respondents clearly indicated a discrepancy between the perception of their own probable behaviour and their conviction about the behaviour of other members of the profession, the condition for the existence of reliability - as a social norm - was not met. The previous research confirms that awareness of the applicable social norms can be an important motivator for specific behaviours, if only an existing norm is defined and clearly communicated to members of a given community. Thus, the indication of the majority of respondents to have made asset write-offs, while not confirming such behaviour as a social norm, poses a big question mark in the context of professional ethics.

The lack of perception of reliability (realized through the entity's true and fair view by means of the created financial information) as an accepted social norm [Bicchieri et al. 2011], significantly undermines professional ethics. The obtained results suggest that other factors may easily lead to the abandonment of ethical behaviour in favour of unethical one. For example, research in the field of social norms clearly indicates the difficulty experienced by people who cheat others if there was direct communication between the parties [Bicchieri, Sontuoso 2015]. In the field of accounting, direct communication is rarely established with the party for which the information presented in the financial statement is prepared, which only increases the risk of providing incorrect financial information. The stakeholders of the entity, including the owners, are an unspecified group of users of financial statements, with whom those who prepare the report would probably have no personal contact.

The validation of both cases in the economic and legal areas as well as the attitudes of decision-makers indicate differentiation depending on the component for which the permanent impairment was established. The observed differences mainly concern awareness of the discrepancy between theory and practice and refraining from reliability is justified by the culture (of the entity, sector etc.).

In the case of tangibles, the respondents more decisively perceive refraining from asset write-offs for egoistic measures and related to the achievement of personal benefits by the decision-maker. The above different responses confirm the adopted hypothesis and indicate that receivables constitute the area considered in the ethical context, while tangible assets gained predominant answers in the area of the existing practice, and not the current assessment made individually by the decision-maker. 


\section{Conclusions}

Discretionary accounting regulations - in the theoretical foundations and assumptions made by the legislature - are used to apply the law in a way that ensures success in accounting, i.e. creating reliable financial information. The study showed that in the area of impairment allowances there is a risk that flexible regulations will not be used to create a true and fair view of the entity, but - due to the lack of confirmation of reliability as a social norm - they can be used (consciously or unconsciously) in a way that undermines reliability. The obtained results suggest further research in the field of the perception of social norms and collective practices by present and future accounting services. The demonstrated ambiguous approach to accounting reliability may indicate the existence of specific patterns of behaviour (attitudes) accepted by accounting services, which may impair the reliability of financial statements [Biccheri et al. 2014].

In addition, the results obtained on the semantic scale confirmed a different approach to asset write-offs depending on the asset component, in relation to which there were indications of permanent impairment. The results suggest that further research in the field of discretionary accounting regulations should ensure the distinction of different asset groups.

\section{References}

Abernethy M.A., Bouwens J., Kroos P., 2017, Organization identity and earnings management, Organizations, Accounting and Society, vol. 58, pp. 1-14.

Anderson S.B., Brown J.L., Hodder L., Hopkins P.E., 2015, The effect of alternative accounting measurement bases on investors' assessments of managers'stewardship, Accounting, Organizations and Society, vol. 46, pp. 100-114.

Bicchieri C., Sontuoso A., 2015, I cannot cheat on you after we talk, www.researchgate.net (15.03.2019).

Bicchieri C., Xiao E., Muldoon R., 2011, Trustworthiness is a social norm, but trusting is not, Politics, Philosophy \& Economics, vol. 10(2), pp. 170-187.

Birnberg J.G., 2011, A proposed framework for behavioural accounting research, Behavioral Research in Accounting, vol. 23(1), pp. 1-43.

Blay A., Gooden E.S., Mellon M.J., Stevens D.E., 2018, The usefulness of social norm theory in empirical business ethics research: A review and suggestions for future research, Journal of Business Ethics, vol. 152, pp. 191-206.

Boedker Ch., Chua W.F., 2013, Accounting as an effective technology: A study of circulation, agency and entrancement, Accounting, Organizations and Society, vol. 38, pp. 245-267.

Booth P., Schulz A.K.-D., 2004, The impact of an ethical environment on managers' project evaluationjudgments under agency problem conditions, Accounting, Organizations and Society, vol. 29, pp. 473-488.

Brown J.O., Popova V.K., 2016, The interplay of management incentives and audit committee communication on auditor judgment, Behavioral Research in Accounting, vol. 28, pp. 27-40.

International Financial Reporting Standards Foundation, 2018, Conceptual Framework for Financial Reporting. 
Maruszewska E.W., 2014, Etyka we współczesnej rachunkowości a wiarygodność informacji w niej tworzonych, Wydawnictwo Uniwersytetu Ekonomicznego w Katowicach.

Mazurowska M., 2014, The role of behavioural research in management accounting, Prace Naukowe Uniwersytetu Ekonomicznego we Wrocławiu, vol. 345, pp. 66-73.

Nowak M., 2016, Konflikt etyczny w pracy księgowego i biegłego rewidenta. Pomiędzy moralnościa ogólna, moralnością roli a interesem własnym, Prace Naukowe Uniwersytetu Ekonomicznego we Wrocławiu, vol. 440, pp. 461-470.

Simnett R., Trotman K.T., 2018, Twenty-five-year overview of experimental auditing research: Trends and links to audit quality, Behavioral Research in Accounting, 30(2), 55-76.

Stronczek A., 2011, Rachunkowość zarządcza w kontekście zachowań członków organizacji, Prace Naukowe Uniwersytetu Ekonomicznego we Wrocławiu, vol. 181, pp. 557-565.

The Accounting Act. 29th September, 1994. O. J. 2018, item 395.

Towry K.L., 2003, Control in a teamwork environment - the impact of social ties on the effectiveness of mutual monitoring contracts, The Accounting Review, vol. 78(4), pp. 1069-1095. 